\title{
Carbon Sequestration Capability Analysis of Urban Green Space Using Geospatial Data
}

\author{
Linda Azaria, Adi Wibowo, Iqbal Putut Ash Shidiq, and Rokhmatuloh* \\ Department of Geography, Faculty of Mathematics and Natural Science, Universitas Indonesia
}

\begin{abstract}
Indonesia is the world's sixth largest producer of Carbon Dioxide $\left(\mathrm{CO}_{2}\right)$ emissions. Jakarta is one of the cities in Indonesia with the highest amount of $\mathrm{CO}_{2}$ emission, due to the growing number of population within the city. Anthropogenic activities in the form of industry, transportation, and housing have become one of the primary sources of $\mathrm{CO}_{2}$ emission. The emission is an urban natural hazard, and it needs to addressed immediately. Green open space is the fundamental solution to this problem. The presence of urban green space will reduce the amount of $\mathrm{CO}_{2}$ emission. Unfortunately, the extent of reduction remains unclear, especially in South Jakarta. The study aims to analyze the capability of urban green space in sequestering $\mathrm{CO}_{2}$ from anthropological aspects such as some population and vehicle in South Jakarta. The sequestration capability of each green open space is measured using the Leaf Area Index generated from remote sensing imagery. The $\mathrm{CO}_{2}$ emission was calculated from some population and the number of vehicles collected from statistical data and ground measurement, respectively. The result shows that green open space distribution significantly correlated with the $\mathrm{CO}_{2}$ sequestration (with the value of 0.79 ). This study shows that the number of urban green space is one of the solutions to reduce $\mathrm{CO}_{2}$ emissions.
\end{abstract}

Keywords: urban green space; co2 sequestration; co2 emissions;geospatial data.

\section{Introduction}

Global warming is a phenomenon of rising earth temperatures due to the production of Greenhouse Gases (GHG) one of the $\mathrm{CO}_{2}$ [1]. In the 1990s about two-thirds of $\mathrm{CO}_{2}$ emissions came from developed countries, but $\mathrm{CO}_{2}$ emissions come from developing countries such as Indonesia, which is the world's sixth largest emitters [2].

Jakarta is the capital of Indonesia which is one of the urban areas. The city of Jakarta which is the capital makes it a center of government and economic activity [3]. The city of Jakarta is the center of activity to make the city of Jakarta has a large population and amount of vehicles, so they make the amount of carbon dioxide emissions getting risen. Large amounts of carbon dioxide emissions can be absorbed with green open space. Green space is a land that consists mostly of surfaces such as grass, shrubs, and trees [4]. Open space defined as part of an urban area that contributes to its ease, both visually by positively contributing to the urban landscape, or based on public access, so that green open space is a combination of green space and public space [4]. South Jakarta is the largest open green city with the widest area of 398.2197 Ha [5]. Also, South Jakarta has the best green open space regarding its utilization in Jakarta [6].

\section{The Study Area}

South Jakarta located at $106^{\circ} 22^{\prime \prime} 42$ 'East Longitude s.d. $106^{\circ} 58^{\prime \prime} 18$ 'east, and $5^{\circ} 19^{\prime \prime} 12$ South Latitude. The total area by the Decision of the Governor of KDKI No. 1815 of 1989 is $141.37 \mathrm{~km}^{2}$ or $22.41 \%$ of the total area of Jakarta [7].

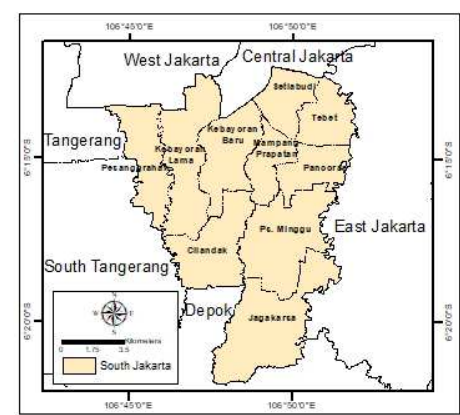

Fig.1. South Jakarta

\section{Methodology}

\subsection{Data}

\subsubsection{Green Open Space Distribution}

The distribution of green open space can know through the fragmentation index [8] with the equation below:

fragmentation index $=\frac{(m-1)}{(n-1)}$

$\mathrm{m}$ : number of green open space polygons in the subdistrict analysis unit

\footnotetext{
* Corresponding author: rokhmatuloh.ssi@ui.ac.id
} 
$\mathrm{n}$ : the total number of polygons in the sub-district analysis unit

The fragmentation index value is between 0 and $1.0-$ 0,5 : the distribution of green open space tend to gather. $0,6-1$ : the distribution of green open space tend to spread.

\subsubsection{Vegetation Index}

The vegetation index is the greenish vegetation value obtained from the digital signal processing of the brightness value data of several satellite sensor data channels. Vegetation index data obtained from SPOT 6 that have processed

Method of vegetation index conducted in this research is using the Leaf Area Index (LAI). LAI defined as the leaf area of each unit of surface area covered by a tree canopy [9]. LAI used through the approach of EVI value. EVI (Enhanced Vegetation Index) is an index developed by MODIS data as an improvement of NDVI. EVI showed by equation [10]:

$\mathrm{EVI}=G *\left(N I R_{\text {Band }}-\operatorname{Red}_{\text {Band }}\right) /\left(\operatorname{NIR}_{\text {Band } 5}+C 1 * \operatorname{Red}_{\text {Band }}\right.$ - $C 2 *$ Blue $\left._{\text {band }}+L\right)$

$\mathrm{L}=1, \mathrm{C} 1=6, \mathrm{C} 2=7.5$, and $\mathrm{G}($ factor gain $)=2.5$

The value of EVI obtained is then entered into the LAI equation [11].

\section{$\mathrm{LAI}=(3.618 \times \mathrm{EVI}-0.118)$}

The vegetation index can determine the type of vegetation and the area of each cover of vegetation. Emission of Carbon Dioxide is the total carbon dioxide emissions in this study based on transportation and anthropogenic. Carbon dioxide emissions from transportation are Carbon dioxide emissions from transport use the equation [12].

Emission $($ ton $/$ year $)=$ volume of vehicle

VKT x EF x $10^{-6}$

VKT: the length of the trip from the vehicle $(\mathrm{km})$

EF: Emission Factor

Vehicle volume data obtained based on the survey. A survey conducted that is taking ten samples according to the number of sub-districts in South Jakarta. Selection of sample using purposive sampling by determining one street that has traffic using Waze application in each subdistrict at peak hour that is from 06.30 until 08.00 on weekdays. The road samples presented in figure 2 .

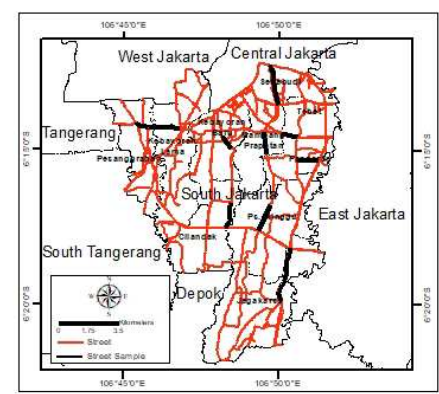

Fig. 2. Road Sample
Table 1. Indonesia Emission Factor (Kementrian Lingkungan Hidup, 2013)

\begin{tabular}{|l|r|r|r|r|l|}
\hline $\begin{array}{l}\text { Vehicle } \\
\text { Category }\end{array}$ & $\mathrm{CO}$ & $\mathrm{HC}$ & $\mathrm{NOx}$ & $\mathrm{CO}_{2}$ & $\mathrm{SO}_{2}$ \\
\hline Motorcycle & 14.0 & 5.9 & 0.29 & 3180 & 0.008 \\
\hline Car & 40.0 & 4.0 & 0.01 & 3180 & 0.026 \\
\hline Truck & 2.8 & 0.2 & 0.53 & 3172 & 0.440 \\
\hline
\end{tabular}

Table 2. Sample Location

\begin{tabular}{|r|l|l|c|}
\hline Sample & Sub-district & Street Name & $\begin{array}{l}\text { Street } \\
\text { Length }\end{array}$ \\
\hline 1 & Cilandak & $\begin{array}{l}\text { Pangeran } \\
\text { Antasari }\end{array}$ & $2.34 \mathrm{~km}$ \\
\hline 2 & Jagakarsa & $\begin{array}{l}\text { Raya Lenteng } \\
\text { Agung }\end{array}$ & $2.45 \mathrm{~km}$ \\
\hline 3 & $\begin{array}{l}\text { Kebayoran } \\
\text { Baru }\end{array}$ & $\begin{array}{l}\text { Iskandar Syah } \\
\text { Raya }\end{array}$ & $0.54 \mathrm{~km}$ \\
\hline 4 & $\begin{array}{l}\text { Kebayoran } \\
\text { Lama }\end{array}$ & Ciledug Raya & $2.4 \mathrm{~km}$ \\
\hline 5 & $\begin{array}{l}\text { Mampang } \\
\text { Prapatan }\end{array}$ & $\begin{array}{l}\text { Mampang } \\
\text { Prapatan }\end{array}$ & $1.53 \mathrm{~km}$ \\
\hline 6 & Pancoran & $\begin{array}{l}\text { Pahlawan } \\
\text { Kalibata }\end{array}$ & $1.27 \mathrm{~km}$ \\
\hline 7 & $\begin{array}{l}\text { Pasar } \\
\text { Minggu }\end{array}$ & Warung Jati & $1.72 \mathrm{~km}$ \\
\hline 8 & Pesanggrahan & Ciledug Raya & $1.93 \mathrm{~km}$ \\
\hline 9 & Setiabudi & Rasuna Said & $2.45 \mathrm{~km}$ \\
\hline 10 & Tebet & Gatot Subroto & $1.01 \mathrm{~km}$ \\
\hline
\end{tabular}

3.1.3.2 Carbon dioxide emissions from anthropogenic

Calculation of emissions of carbon dioxide from anthropogenic emissions released by human respiration. The amount of carbon dioxide emitted during the respiratory process is assumed to be the same for every human [13].

Emissions $(\mathrm{kg} /$ day $)=$ population x $0.9504 \mathrm{~kg} /$ day $\quad$ (5)

Emissions (to /year) $=$ population $\times 0.347$ ton/year (6)

\subsubsection{Absorption of Carbon Dioxide Emissions}

The absorption capacity of carbon dioxide obtained through the equation (Prasetyo, 2002 cited in Rawung, 2015): The absorption of carbon dioxide (ton/year) = $\mathrm{CO}_{2}$ absorption by type of vegetation $\mathrm{x}$ vegetation cover area (7)

Table 3. $\mathrm{CO}_{2}$ Absorption

\begin{tabular}{|l|r|r|}
\hline Vegetation type & $\begin{array}{l}\mathrm{CO}_{2} \text { Absorption } \\
\text { (kg/ha/hour) }\end{array}$ & $\begin{array}{l}\mathrm{CO}_{2} \text { Absorption } \\
\text { (ton/ha/year) }\end{array}$ \\
\hline Tree & 129.92 & 569.07 \\
\hline Grass & 2.74 & 12.00 \\
\hline
\end{tabular}

\subsubsection{Residual of Carbon Dioxide Emissions}

The residual carbon dioxide emissions obtained from the equation [14]: 
Residual emissions $=$ Total emissions of $\mathrm{CO}_{2}-$ absorption of $\mathrm{CO}_{2}$ emissions

\subsection{Analysis}

The analysis used is descriptive analysis and correlation analysis to determine the strength of the relationship between green open space distribution and the absorption of carbon dioxide emissions by vegetation. Correlation analysis used in this research is the Spearman rank.

\section{Result}

\subsection{Green Open Space Distribution}

The fragmentation index can know the distribution of green open space in each sub-district of South Jakarta. Fragmentation index in ten sub-districts in South Jakarta has a value less than 0.5 which means green open space tend to gather in each sub-district.

Table 4. Fragmentation Index

\begin{tabular}{|l|r|r|r|}
\hline $\begin{array}{l}\text { Sub- } \\
\text { district }\end{array}$ & $\begin{array}{l}\text { GOS } \\
\text { (polygon) }\end{array}$ & $\begin{array}{l}\text { NONGOS } \\
\text { (polygon) }\end{array}$ & $\begin{array}{l}\text { Fragmentation } \\
\text { Index }\end{array}$ \\
\hline Cilandak & 298 & 601 & 0.3307 \\
\hline Jagakarsa & 549 & 560 & 0.4945 \\
\hline $\begin{array}{l}\text { Kebayoran } \\
\text { Baru }\end{array}$ & 362 & 703 & 0.3392 \\
\hline $\begin{array}{l}\text { Kebayoran } \\
\text { Lama }\end{array}$ & 494 & 661 & 0.4272 \\
\hline $\begin{array}{l}\text { Mampang } \\
\text { Prapatan }\end{array}$ & 151 & 407 & 0.2693 \\
\hline Pancoran & 478 & 397 & 0.3777 \\
\hline $\begin{array}{l}\text { Pasar } \\
\text { Minggu }\end{array}$ & 421 & 464 & 0.4599 \\
\hline $\begin{array}{l}\text { Pesanggra- } \\
\text { han }\end{array}$ & 177 & 437 & 0.4751 \\
\hline Setiabudi & 221 & 357 & 0.2871 \\
\hline Tebet & & & 0.3812 \\
\hline
\end{tabular}

GOS: Green Open Space

\subsection{Emission of Carbon Dioxide}

\subsubsection{Transportation and Population Data}

Transportation data divided into two data, motorcycle and car (see Table 5). Population data divided into ten according to the number of sub-districts in South Jakarta (see Table 6).

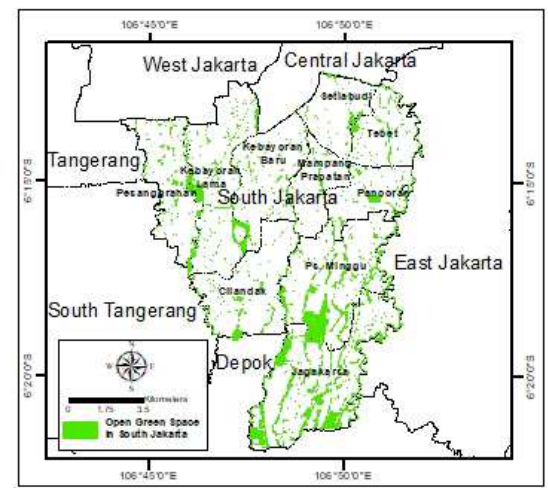

Fig.3. Green Open Space in South Jakarta

Table 5. Number of Vehicles On Weekdays (260 days) Motorcycle (M) and Car (C) in Each Subdistrict in South Jakarta

\begin{tabular}{|l|c|r|}
\hline \multicolumn{1}{|c|}{ Kecamatan } & M & \multicolumn{1}{c|}{ C } \\
\hline Cilandak & $3,293,811$ & $1,138,529$ \\
\hline Jagakarsa & $7,642,149$ & $1,269,553$ \\
\hline Kebayoran Baru & $5,268,407$ & $1,564,091$ \\
\hline Kebayoran Lama & $4,232,107$ & 554,471 \\
\hline Mampang Prapatan & $6,178,702$ & $1,222,268$ \\
\hline Pancoran & $3,351,134$ & 456,996 \\
\hline Pasar Minggu & $2,466,990$ & 659,871 \\
\hline Pesanggrahan & $1,994,408$ & 283,707 \\
\hline Setiabudi & $5,551,322$ & $2,169,546$ \\
\hline Tebet & $7,117,791$ & 955,466 \\
\hline
\end{tabular}

\subsubsection{Emissions Data}

The highest total carbon dioxide emissions are in Jagakarsa sub-district at 137,381.69 tons/year while the lowest total carbon dioxide emissions in Setiabudi subdistrict are 44,738.56 tons/year.

Table 6. Population Data

\begin{tabular}{|l|r|}
\hline Sub-district & Population \\
\hline Cilandak & 200,358 \\
\hline Jagakarsa & 378,877 \\
\hline Kebayoran Baru & 143,577 \\
\hline Kebayoran Lama & 306,544 \\
\hline Mampang Prapatan & 146,130 \\
\hline Pancoran & 153,819 \\
\hline Pasar Minggu & 305,259 \\
\hline Pesanggrahan & 221,584 \\
\hline Setiabudi & 139,596 \\
\hline Tebet & 210,978 \\
\hline
\end{tabular}


Table 7. Total Emissions of Carbon Dioxide

\begin{tabular}{|l|r|r|r|}
\hline Sub-district & $\begin{array}{c}\text { Transportation } \\
\text { Emissions } \\
\text { (ton/year) }\end{array}$ & $\begin{array}{c}\text { Antrho- } \\
\text { pogenic } \\
\text { Emission } \\
\text { (ton/year) }\end{array}$ & $\begin{array}{c}\text { Total } \\
\text { Emission of } \\
\text { CO2 } \\
\text { (ton/year) }\end{array}$ \\
\hline Cilandak & $3,134.38$ & $71,304.68$ & $74,439.51$ \\
\hline Jagakarsa & $5,915.54$ & $131,466.15$ & $137,381.69$ \\
\hline $\begin{array}{l}\text { Kebayoran } \\
\text { Baru }\end{array}$ & 248.29 & $49,655.00$ & $49,903.30$ \\
\hline $\begin{array}{l}\text { Kebayoran } \\
\text { Lama }\end{array}$ & $2,929.74$ & $106,371.80$ & $109,301.54$ \\
\hline $\begin{array}{l}\text { Mampang } \\
\text { Prapatan }\end{array}$ & $1,976.21$ & $50,706.76$ & $52,682.97$ \\
\hline Pancoran & 656,49 & $56,642.54$ & $57,299.04$ \\
\hline Pasar Minggu & $1,121.43$ & $105,922.09$ & $107,043.52$ \\
\hline Pesanggrahan & 913.70 & $76,887.56$ & $77,801.26$ \\
\hline Setiabudi & $6,129.96$ & $38,608.60$ & $44,738.56$ \\
\hline Tebet & 878.48 & $73,209.36$ & $74,087.85$ \\
\hline
\end{tabular}

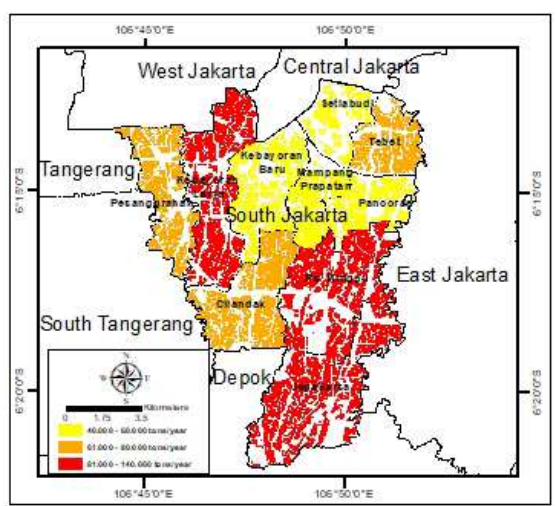

Fig.4. Total Emissions in South Jakarta

Total carbon dioxide emissions divided into three levels. The low level is the total value of carbon dioxide emissions from 40.000 tons/year to 60.000 tons/year. The middle class is the total value of carbon dioxide emissions from 61,000 tons/year to 80,000 tons/year. The high level is the total value of carbon dioxide emissions from 81,000 tons/year to 140,000 tons/year.

\subsection{Absorption of Carbon Dioxide Emissions}

The absorption capacity of carbon dioxide emissions by green open space in South Jakarta amounted to 337,259.92 tons/year with Setiabudi Sub-district which has the lowest absorption of carbon dioxide emission of 3,960.01 tons/year and green open space in Jagakarsa sub-district which has the highest absorption capacity of carbon dioxide of 121,573.26 tons/year.

\subsection{Residual of Carbon Dioxide Emissions}

The highest residual carbon dioxide emissions in Kebayoran Lama Sub-district are 68,674.51 tons/year, and the lowest in Jagakarsa Sub-district is $15,808.43$ tons/year.
Table 8. Absorption of Carbon Dioxide Emissions

\begin{tabular}{|c|c|c|c|}
\hline \multirow{2}{*}{ Sub-district } & \multicolumn{2}{|c|}{ Vegetation $(\mathrm{Ha})$} & \multirow{2}{*}{$\begin{array}{c}\text { Total } \\
\text { Absorptions } \\
\text { (tons/year) }\end{array}$} \\
\hline & Grass & Tree & \\
\hline Cilandak & 14.10 & 39.56 & $22,681.79$ \\
\hline Jagakarsa & 70.53 & 212.14 & $121,573.26$ \\
\hline $\begin{array}{l}\text { Kebayoran } \\
\text { Baru }\end{array}$ & 11.82 & 43.28 & $24,773.21$ \\
\hline $\begin{array}{l}\text { Kebayoran } \\
\text { Lama }\end{array}$ & 24.56 & 70.87 & $40,627.03$ \\
\hline $\begin{array}{l}\text { Mampang } \\
\text { Prapatan }\end{array}$ & 5.18 & 9.48 & $5,462.06$ \\
\hline Pancoran & 11.47 & 11.55 & $6,715.62$ \\
\hline Pasar Minggu & 41.64 & 154.71 & $88,541.67$ \\
\hline Pesanggrahan & 18.13 & 28.45 & $16,411.28$ \\
\hline Setiabudi & 6.31 & 6.82 & $3,960.01$ \\
\hline Tebet & 8.70 & 11.26 & $6,513.95$ \\
\hline
\end{tabular}

The residual of carbon dioxide emissions divided into three levels. The low level is the value of residual of carbon dioxide emissions from 15,000 tons/year to 30,000 tons/year. The middle class is the value of residual of carbon dioxide emissions from 31,000 tons/year to 50.000 tons/year. The high level is the residual value of carbon dioxide emissions from 51,000 tons/year to 70,000 tons/year.

\subsection{The Relationship between The Characteristics of Green Open Space Distribution and The Absorption of Carbon Dioxide Emissions}

The distribution of green open spaces in South Jakarta tends to gather based on fragmentation index that has a value less than 0.5 in ten sub-districts. The distribution of green open space has a significant effect on the absorption capacity of carbon dioxide emission based on statistical test result with a significance value of 0.22 . Based on the data obtained, the green open spaces that gather have a significant influence and have a positive influence. The positive influence means that the green open space is getting together, the higher the absorption capacity of carbon dioxide emissions. Also, the distribution of green open space and carbon dioxide emission absorption have interrelated relationships based on correlation test results with a correlation coefficient of 0.79 .

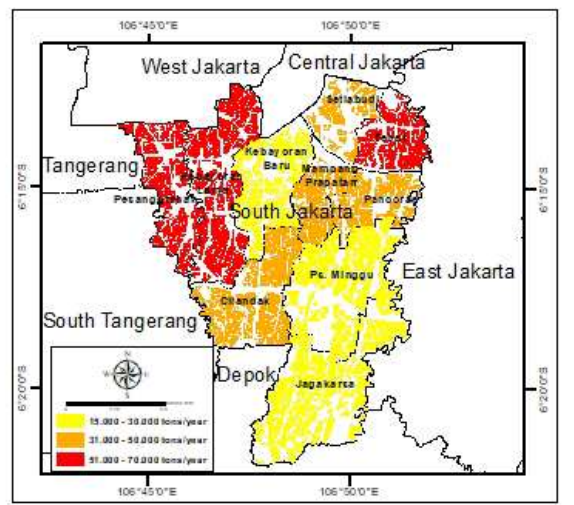

Fig.5. Residual of CO2 Emissions in South Jakarta 
Table 9. Residual of Carbon Dioxide Emissions

\begin{tabular}{|l|r|}
\hline Sub-district & $\begin{array}{l}\text { Residual carbon dioxide } \\
\text { emissions (tons/year) }\end{array}$ \\
\hline Cilandak & $51.757,72$ \\
\hline Jagakarsa & $15.808,43$ \\
\hline Kebayoran Baru & $25.130,09$ \\
\hline Kebayoran Lama & $68.674,51$ \\
\hline Mampang Prapatan & $47.220,92$ \\
\hline Pancoran & $50.583,41$ \\
\hline Pasar Minggu & $18.501,85$ \\
\hline Pesanggrahan & $61.389,98$ \\
\hline Setiabudi & $40.778,55$ \\
\hline Tebet & $67.573,9$ \\
\hline
\end{tabular}

\begin{tabular}{|c|c|c|c|c|}
\hline \multicolumn{5}{|c|}{ Correlations } \\
\hline & & & Dist & Absorp \\
\hline \multirow[t]{6}{*}{ Spearman's rho } & \multirow[t]{3}{*}{ Dist } & Correlation Coefficient & 1.000 & .709 \\
\hline & & Sig. (2-tailed) & & .022 \\
\hline & & $\mathrm{N}$ & 10 & 10 \\
\hline & \multirow[t]{3}{*}{ Absorp } & Correlation Coefficient & $.709^{\prime}$ & 1.000 \\
\hline & & Sig. (2-tailed) & .022 & \\
\hline & & $\mathrm{N}$ & 10 & 10 \\
\hline
\end{tabular}

Fig.6. Correlation Table

\section{Conclusion}

Distribution of green open space in ten districts in South Jakarta tends to cluster with fragmentation index value less than 0.5 . The absorption capacity of carbon dioxide emissions by the smallest green open space found in Setiabudi Sub-district and the most massive absorption capacity of carbon dioxide emission green open space is Jagakarsa Sub-district. The lowest total carbon dioxide emissions are Setiabudi Sub-district, and the most significant total carbon dioxide emissions are Jagakarsa Sub-district. The lowest residual carbon dioxide emissions are Jagakarsa Sub-district, then the most massive residual carbon dioxide emissions are Kebayoran Lama Sub-district. The distribution of green open space has a significant effect on the absorption of carbon dioxide emissions. The distribution of green open space and carbon dioxide emission absorption have interrelated relationships based on correlation test results with a correlation coefficient of 0.79 .

\section{Acknowledgement}

This study is supported and funded by University of Indonesia under the Publikasi Terindeks International untuk Tugas Akhir Mahasiswa (Hibah PITTA) research grant 2018.

\section{References}

1. Achmad, Rukaesih. Kimia Lingkungan. Yogyakarta: Andi (2004)

2. National Geographic Indonesia. Indonesia Jadi Negara Pengemisi Terbesar Keenam di Dunia (2014). Retrieved January 30, 2018, from http://nationalgeographic.co.id/berita/2014/10/indonesiajadi-negara-pengemisi-terbesar-keenam-di-dunia

3. Provinsi DKI Jakarta. Seri Analisis Pembangunan Wilayah. Jakarta: Bappenas (2015)

4. Swanwick C, Dunnet N, Woolley H. Nature, Role and Value of Green Space in Towns and Cities: An Overview. Built Environment (1978-), Vol. 29, No. 2, Perspectives on Urban Greenspace in Europe (2003), pp. 94-106

5. Provinsi DKI Jakarta. Data Ruang Terbuka Hijau DKI Jakarta. (2016) Available: http://data.jakarta.go.id/dataset/ruangterbukahijaudkijakart a

6. Novianty Rizka, Neolaka A, Rahmayanti H. Evaluasi Mengenai Kuantitas dan Kualitas Ruang Terbuka Hijau di Wilayah DKI Jakarta. Jurnal Menara Fakultas Teknik Sipil Universitas Negeri Jakarta Volume VII No. 1 Januari 2012 ISSN: 1907 - 4360

7. BPS Jakarta Selatan. Jakarta Selatan dalam Angka. (2017)

8. Tjumardi, R. S. Analisis Sebaran dan Kecukupan Ruang Terbuka Hijau untuk Mendukung Program Pengembangan Kota Hijau di Kabupaten Ciamis. Thesis. Bogor: Institut Pertanian Bogor (2015)

9. Suwarsono, Arief, M., Sulma, S., H, N. S., Sulyantoro, H., \& Setiawan, K. T. Pengembangn Metode Penentuan Indeks Luas Daun pada Penutup Lahan Hutan dari Data Satelit Penginderaan Jauh SPOT-2. Penginderaan Jauh, 8 , 50-59 (2011)

10. Boegh, E, et al. Airborne Multispectral Data for Quantifying Leaf Area Index, Nitrogen Concentration, and Remote Sensing of Environment, 81, 179-193. (2002).. https://doi.org/10.1016/S0034-4257(01)00342-X

11. Huete, Alfredo, Kamel Didan, Tomoaki Miura, E. Patricia Rodriguez, Xiang Gao, and Laerte G. Ferreira. "Overview of the radiometric and biophysical performance of the MODIS vegetation indices." Remote sensing of environment 83, no. 1-2 (2002): 195-213. http://www.sciencedirect.com/science/article/pii/S003442 $\underline{5702000962}$

12. Kementrian Lingkungan Hidup. Pedoman Teknis Penyusunan Inventarisasi Emisi Pencemar Udara di Perkotaan. Jakarta: Kementrian Lingkungan Hidup (2013)

13. Rivai A, Latifah S, Pindi P. Pendugaan Emisi $\mathrm{CO}_{2}$ dan Kebutuhan $\mathrm{O}_{2}$ Serta Daya Serap $\mathrm{CO}_{2}$ dan Penghasil $\mathrm{O}_{2}$ pada Taman Kota dan Jalur Hijau di Kota Medan. Medan: Universitas Sumatera Utara. (2015)

14. Rawung C Frankie. Efektivitas Ruang Terbuka Hijau (RTH) dalam Mereduksi Gas Rumah Kaca (GRK) di Kawasan Perkotaan Boroko. Jurnal Media Matrasain Volume 12, No.2, Juli 2015 ISSN 1858-1137. (2015) 